\title{
EDITORIAL—JUST HOW COMPARATIVE IS COMPARATIVE URBAN GEOGRAPHY? A PERSPECTIVE FROM ARCHAEOLOGY ${ }^{1}$
}

\author{
Michael E. Smith ${ }^{2}$ \\ School of Human Evolution and Social Change \\ Arizona State University
}

A series of recent papers in Urban Geography on "comparative urbanism" (Robinson, 2004; Dear, 2005; Nijman, 2007a; Ward, 2008) raises concerns about the domain within which urban geographers undertake comparisons. Nearly all discussion concerns contemporary and very recent historical cities with little serious consideration of ancient or preindustrial cities (one exception is early modern Amsterdam; Nijman, 2007b). There may be good reasons for limiting consideration to modern urban settings, and it is not clear that drawing ancient cities into the mix would improve our understanding of the cities included in this journal. Nonetheless, at least one of the papers advocates this wider domain of comparison.

Jan Nijman opens his introductory essay to a special issue on comparative urbanism with this statement: "Comparative urbanism, as a field of inquiry, aims at developing knowledge, understanding, and generalization at a level between what is true of all cities and what is true of one city at a given point in time" (Nijman, 2007a, p. 1). Comparative analysis can play several roles in advancing scholarship. It aids in the identification of both regularities and anomalies or unique cases. But to achieve an adequate perspective on the range of variation in urban phenomena ("what is true of all cities") will require scholars to broaden their perspective beyond the modern and recent eras, and archaeologists are now poised to make contributions to this effort.

In the past few decades, archaeological data on ancient cities and urban systems have expanded tremendously, and a growing number of my colleagues are engaging with urban theory and analyzing (or reanalyzing) their data to help build a foundation for a broader comparative approach to urbanism (Fletcher, 1995; Smith, 2003; Storey, 2006; Sabloff, 2008; Smith, n.d.). For example, an active topic of archaeological fieldwork and comparative analysis today is the low-density agrarian city as mapped and excavated in Asia, Africa, and the Americas. Roland Fletcher $(1986,1995)$ identified these settlementswith their impressive public architecture surrounded by extensive areas of settlement and farming - as a distinctive type of city in ancient times with parallels in the modern world. Fletcher has continued work on this topic through fieldwork at Angkor (Evans et al.,

\footnotetext{
${ }^{1}$ I would like to thank the following colleagues for helpful suggestions concerning this editorial: Christopher Boone, George Cowgill, Gary Feinman, Roland Fletcher, Jill Grant, Cynthia Heath-Smith, Juliana Novic, Wendy Plotkin, Jeremy Sabloff, Andrew Sluyter, Monica Smith, and Barbara Stark. I also thank the editors of Urban Geography for encouraging me to prepare this essay.

${ }^{2}$ Correspondence concerning this article should be addressed to Michael E. Smith, School of Human Evolution and Social Change, Box 872402, Arizona State University, Tempe, Arizona 85287; telephone: 480-727-9520; fax: 480-967-7671; e-mail: mesmith9@asu.edu
} 
2007) and explicit comparisons with modern conurbations (Fletcher, n.d.). Others are researching the use and significance of open spaces within ancient, low-density cities (Feinman et al., 2002; Robin, 2002; Stark and Ossa, 2007; Hutson et al., 2008), surely a topic that resonates with research on spatial patterns in modern cities (Garde, 1999; Al-Hagla, 2008; Simon, 2008).

Other topics of potential interest to scholars who study modern urbanism have been the subjects of archaeological research for decades, often using methods and approaches drawn from geography. For example, rank-size analysis of city systems has long been a staple of regional archaeological settlement research (Kowalewski, 1982; Savage, 1997; Drennan and Peterson, 2004). Similarly, many archaeologists have analyzed rural-urban interactions and the embeddedness of cities in their regional systems (Blanton, 1982; Falconer, 1995; Adams, 2008).

Nevertheless, the phenomenon of "recentism" works against the comparative study of ancient and modern cities. Recentism is the situation in which historical scholarship on social topics focuses increasingly on later periods at the expense of earlier ones. Rhys Jones (2004) documents recentism in historical geography through a citation analysis of journals (see also Jones and Phillips, 2005). The phrase "recentism" was proposed by Andrew Sluyter (2005) for Latin American environmental history. Recentism in urban studies is certainly not limited to geography (Smith, 1991). Urban historians use the term "temporal parochialism" to describe the tendency for articles in urban history journals to concentrate on very recent cities at the expense of those that flowered prior to 1850 (Blumin, 1994; McShane, 2006).

Some scholars of modern urbanism are not hindered by recentism, however, and they do regard ancient cities as worthy for comparative purposes. Urban planner Jill Grant (2001, 2004), for example, uses data on ancient cities to broaden the comparative understanding of orthogonal planning and urban sustainability. Architect Besim Hakim (2001, 2008) shows that ancient and traditional Islamic principles of urban design can illuminate and guide modern practices. Archaeological settlement data are cited by geographer David Simon (2008) and architectural historian Robert Bruegmann (2005) in their respective accounts of periurban areas and urban sprawl. Geographer Edward Soja appears to take ancient urbanism seriously, although few archaeologists would agree with his characterization of Turkey's 15-hectare Neolithic village site of Çatalhöyük as an "urban" settlement (Soja, 2000, pp. 36-49), or his assertion that "all over the world the pre-industrial city looks almost the same" (Soja, 2002, p. 149). Finally, geographers Christopher Boone and Ali Modarres (2006) begin their book, City and Environment, with a review of ancient cities and their environmental interactions.

Another issue that hinders ancient-modern urban comparisons operates within archaeological scholarship: archaeologists have failed to analyze our data or conceptualize our findings in terms that facilitate comparison with modern and historical cities (Smith, 2008). Urban sustainability provides an example. Archaeological survey has documented the historical trajectories of thousands of ancient cities, and it should be possible to identify systematic factors that might explain why some cities lasted much longer than others. To what extent is the variation caused by environmental setting, by political context, and/ or by other factors? Yet when I tried to look into this question, I found that no one had assembled their data in ways that could be analyzed to address variation in longevity or sustainability (Smith, 2008). Archaeologists have the information to address these and 
other questions of interest to scholars of modern urbanism, but it will take considerable effort and analysis before our data can be marshaled for this purpose.

Perhaps modern cities are so radically different from their earlier predecessors that scholars of modern urbanism can safely ignore the $96 \%$ of urban history prior to the Industrial Revolution. After all, factors such as transportation technology, nation-state dynamics, and, above all, global capitalism (with its flows of capital, goods, people, and information) conspire to make modern cities very different places embedded within very different social contexts vis-à-vis their ancient counterparts. Nevertheless, we still have little reliable evidence about the nature and the extent of similarities and differences between ancient and modern cities. This empirical question has yet to be answered.

In 1977, geographer James Vance published one of the most wide-ranging and explicitly comparative treatments of urban morphology ever attempted (Vance, 1977; for an updated edition, see Vance, 1990; see also Morris, 1994). Since 1977, however, recentism has worked to keep premodern cities outside many domains of comparative urbanism. If urban geographers wish to explore "what is true of all cities" they will need to establish a much broader arena for comparison than is evident in recent papers in Urban Geography. There are archaeologists and urban historians who would welcome the participation of geographers in such a broadened comparative effort. On the other hand, if geographers are content to limit consideration to modern urbanization, perhaps they should be more precise in describing the nature of their comparative enterprise.

\section{REFERENCES}

Adams, R. M., 2008, An Interdisciplinary Overview of a Mesopotamian City and its Hinterlands. Cuneiform Digital Library Journal, 2008: 1. Retrieved from http:// www.cdli.ucla.edu/pubs/cdlj/2008/cdlj2008_001.html

Al-Hagla, K., 2008, Towards a sustainable neighborhood: The role of open spaces. International Journal of Architectural Research, Vol. 2, 162-177.

Blanton, R. E., 1982, Urban beginnings: A view from anthropological archaeology. Journal of Urban History, Vol. 8, 427-446.

Blumin, S. M., 1994, City limits: Two decades of urban history in JUH. Journal of Urban History, Vol. 21, 7-30.

Boone, C. G. and Modarres, A., 2006, City and Environment. Philadelphia, PA: Temple University Press.

Bruegmann, R., 2005, Sprawl: A Compact History. Chicago, IL: University of Chicago Press.

Dear, M., 2005, Comparative urbanism. Urban Geography, Vol. 26, 247-251.

Drennan, R. D. and Peterson, C. E., 2004, Comparing archaeological settlement systems with rank-size graphs: A measure of shape and statistical confidence. Journal of Archaeological Science, Vol. 31, 533-549.

Evans, D., Pottier, C., Fletcher, R., Hensley, S., Tapley, I., Milne, A., and Barbetti, M., 2007, A comprehensive archaeological map of the world's largest preindustrial settlement complex at Angkor, Cambodia. Proceedings of the National Academy of Sciences, Vol. 104, 14277-14282. 
Falconer, S. E., 1995, Rural responses to early urbanism: Bronze age household and village economy at Tell el-Hayyat, Jordan. Journal of Field Archaeology, Vol. 22, 399-419.

Feinman, G. M., Nicholas, L. M., and Haines, H. R., 2002, Houses on a hill: Classic period domestic life at El Palmillo, Oaxaca, Mexico. Latin American Antiquity, Vol. 13, 251-278.

Fletcher, R., 1986, Settlement archaeology: Worldwide comparisons. World Archaeology, Vol. 18, 59-83.

Fletcher, R., 1995, The Limits of Settlement Growth: A Theoretical Outline. New York, NY: Cambridge University Press.

Fletcher, R., n.d., Low-density, agrarian-based urbanism: Scale, power and ecology. In M. E. Smith, editor., The Comparative Archaeology of Complex Societies. (In preparation)

Garde, A. M., 1999, Marginal spaces in the urban landscape: Regulated margins or incidental open spaces? Journal of Planning Education and Research, Vol. 18, 200-210.

Grant, J., 2001, The dark side of the grid: Power and urban design. Planning Perspectives, Vol. 16, 219-241.

Grant, J., 2004, Sustainable urbanism in historical perspective. In A. Sorensen, P. J. Marcutullio, and J. Grant, editors., Towards Sustainable Cities: East Asian, North American and European Perspectives on Managing Urban Regions. Burlington, VT: Ashgate, 24-37.

Hakim, B. S., 2001, Julian of Ascalon's treatise of construction and design rules from sixth-century Palestine. Journal of the Society of Architectural Historians, Vol. 60, 4 25 .

Hakim, B. S., 2008, Mediterranean urban and building codes: Origins, content, impact, and lessons. Urban Design International, Vol. 13, 21-40.

Hutson, S. R., Hixson, D. R., Magnoni, A., Mazeau, D. E., and Dahlin, B. H., 2008, Site and community at Chunchucmil and ancient Maya urban centers. Journal of Field Archaeology, Vol. 33, 19-40.

Jones, R., 2004, What time historical geography? Progress in Human Geography, Vol. 28, 287-304.

Jones, R. and Phillips, R., 2005, Unsettling geographical horizons: Exploring premodern and non-European imperialism. Annals of the Association of American Geographers, Vol. 95, 141-161.

Kowalewski, S. A., 1982, The evolution of primate regional systems. Comparative Urban Research, Vol. 9, 60-78.

McShane, C., 2006, The state of the art in North American urban history. Journal of Urban History, Vol. 32, 582-597.

Morris, A. E. J., 1994, History of Urban Form: Before the Industrial Revolution. New York, NY: Longman.

Nijman, J., 2007a, Introduction: Comparative urbanism. Urban Geography, Vol. 28, 1-6.

Nijman, J., 2007b, Place-particularity and "deep analogies": A comparative essay on Miami's rise as a world city. Urban Geography, Vol. 28, 92-107.

Robin, C., 2002, Outside of houses: The practices of everyday life at Chan Noohol, Belize. Journal of Social Archaeology, Vol. 2, 245-268. 
Robinson, J., 2004, In the tracks of comparative urbanism: Difference, urban modernity and the primitive. Urban Geography, Vol. 25, 707-723.

Sabloff, J. A., 2008, Archaeology Matters: Action Archaeology in the Modern World. Walnut Creek, CA: Left Coast Press.

Savage, S. H., 1997, Assessing departures from log-normality in the rank-size rule. Journal of Archaeological Science, Vol. 24, 233-244.

Simon, D., 2008, Urban environments: Periurban issues. Annual Review of Environment and Resources, Vol. 33, 167-185.

Sluyter, A., 2005, Recentism in environmental history on Latin America. Environmental History, Vol. 10.

Smith, D. A., 1991, Method and theory in comparative urban studies. International Journal of Comparative Sociology, Vol. 32, 39-58.

Smith, M. E., 2008, Ancient Cities: Do They Hold Lessons For the Modern World? Paper presented at the 73rd Annual Meeting, Society for American Archaeology, Vancouver, British Columbia, Canada.

Smith, M. E., n.d., Conceptual and comparative framework for the study of urban neighborhoods in ancient Mesoamerica. In L. Manzanilla and C. Arnauld, editors., Neighborhoods in Mesoamerican Cities: The Assessment of Intermediate Units of Spatial and Social Analysis. (In preparation)

Smith, M. L., editor., 2003, The Social Construction of Ancient Cities. Washington, DC: Smithsonian Institution Press.

Soja, E. W., 2000, Postmetropolis: Critical Studies of Cities and Regions. Malden, MA: Blackwell.

Soja, E. W., 2002, Spatiality past and present: An interview with Edward Soja, Los Angeles, 12 April 2001 (interview by Emma Blake). Journal of Social Archaeology, Vol. 2, 139-158.

Stark, B. L. and Ossa, A., 2007, Ancient settlement, urban gardening, and environment in the gulf lowlands of Mexico. Latin American Antiquity, Vol. 18, 385-406.

Storey, G., editor., 2006, Urbanism in the Preindustrial World: Cross-Cultural Approaches. Tuscaloosa, AL: University of Alabama Press.

Vance, J. E., Jr., 1977, This Scene of Man: The Role and Structure of the City in the Geography of Western Civilization. New York, NY: Harper and Row.

Vance, J. E., Jr., 1990, The Continuing City: Urban Morphology in Western Civilization. Baltimore, MD: Johns Hopkins University Press.

Ward, K., 2008, Editorial: Toward a comparative (re)turn in urban studies? Some reflections. Urban Geography, Vol. 29, 405-410. 